\title{
Eating and Representing: Transcultural Approaches to Practices of Nutrition.
}

\section{Claire DODANE}

\section{(2) OpenEdition \\ Journals}

Electronic version

URL: http://journals.openedition.org/transtexts/588

DOI: $10.4000 /$ transtexts.588

ISSN: 2105-2549

Publisher

Gregory B. Lee

Electronic reference

Claire DODANE, "Eating and Representing: Transcultural Approaches to Practices of Nutrition. », Transtext(e)s Transcultures 跨文本跨文化 [Online], 10 | 2015, Online since 08 August 2016, connection on 22 September 2020. URL : http://journals.openedition.org/transtexts/588 ; DOI : https://doi.org/ $10.4000 /$ transtexts.588

This text was automatically generated on 22 September 2020.

(c) Tous droits réservés 


\title{
Eating and Representing: Transcultural Approaches to Practices of Nutrition.
}

\author{
Claire DODANE
}

1 In the first part of this issue of Transtext(e)sTranscultures we publish papers emanating from the international conference organized by IETT $12^{\text {th }}-14^{\text {th }}$ December 2012 at Lyons 3 University.

2 The conference was entitled: "Eating and Representing: Transcultural Approaches to Practices of Nutrition". The IETT being geographically based in Lyons, a city famous for its gastronomy, the ambition of the organizers was to encourage participants to engage in a shared reflexion likely to create connections with the community; the intervention of several professionals from the world of cuisine during the seminar enriched this transdisciplinary debate. "Reading food and living it" could have also been chosen to designate this conference which discussed the act of eating through its textual representations (literature, film, media, advertisements, tourism-related publications) and through a plurality of different cultures.

3 Numerous specialists from various disciplines came together at the conference -including colleagues from English Studies, Asian Studies, Hispanic Studies, Mediterranean Studies, French literature, philosophy, history, management, communication studies and even Chinese medicine - to reflect on practices eating and feeding centred on four pre-defined themes: the body, identity, risk and environment, and pleasure in the love of good food. At a point in time when Food Studies are gaining ground in English-speaking countries and when daily news addresses both the pleasures of eating is and at the same time expresses grave concerns over global food risks, we deliberately decided to focus on the fact that eating, a daily necessity but never an innocent deed, is always once hunger is satisfied, a matter of identity, because we just do not eat consume mere nutriments but also representation and imagination. 


\section{Keynote Lecture}

4 "La faim comme origine de la parole" (Hunger as the origin of the word) by Jérôme Thélot appropriately reminds us to what extent hunger, "the law of all laws" stands chronologically first as a phenomenon, consequently conditioning any other decision or action. Hunger is not aware of itself, but is felt and this original affect is the necessary condition of all possible knowledge. Philosophically, thinking feeds on by literary representations and calls on "A season in hell" by Rimbaud, The Iliad by HOMER and The Divine Comedy by Dante, all united by the same cry : "I must eat to live". Once this need is dealt with, thinking can happen.

\section{Identity and Religion}

5 The kitchen is the place of invention and re-invention of traditions, the building of national, ethnic, diasporic and community identities. From the acceptance to religious taboos to logics of exclusion, the meal forms the basis and unity of the group that shares it. Advertisements just as tourist literature celebrating the flavours and culinary exoticism of the Others turns gastronomy into the privileged vehicle of stereotypes. The memory of a particular taste transmitted, cultivated and cooked from generation to generation stems from the obvious link between between food and family identity ; As Pierre Bourdieu explains in Distinction: A Social Critique of the Judgement of Taste "having taste, having good taste" is often a matter of identifying oneself with a social class. The notion of norms or identity is similarly present in the relationship between men and women in the face of food. From the wife confined to the kitchen to the Michelin-starred chefs in famous restaurants, it is public-private space that is at stake. the question deals with the private/public spaces, whereas choc ices in advertisements evoke the sexual appetite of the instrumentalized woman that feminists continuously denounce . Different generations do not harbour the same culinary tastes, while at the same time a particular food can provoke nostalgia for childhood or an idealized national identity .

6 "Cacherout en déroute : études de certains comportements remarquables vis-à-vis des lois sur l'alimentation dans le judaïsme en temps de crise" (The retreat from kashrut: reflections on certain instances of remarkable behaviour regarding Jewish dietary laws in time of crisis") by Hervé Gabrion recounts the singular ways in which individuals or communities apply the diet imposed by normative Judaism and the Bible. He discuses the collective case situation of eighteenth-century Sabbateans in Poland, and the individual case of Isaac Deutscher, known for his biography of Trotsky, two examples that show the difficulty of breaking free from subjugation to the identity cement constituted by laws governing our eating habits.

7 "La cuisine coréenne comme représentation de la communauté nationale : analyse des rapports entre communauté et cuisine dans les films Sikgaek et Sikgaek 2" by Aurélien Pasquier, discusses the archetypal South Korean food, Kimchi, considered a lowly repast until the beginning of the 1960s in South Korea due to its strong smell. Rehabilitated in the 1980s and produced in large quantities in both Korea and Japan because of its beneficial effects for the health. The representation of this highly 
symbolic aliment is analysed through the two parts of the film Sikgaek or Le grand chef and demonstrates the part played by food in the building of national identity.

The feeling of belonging to a community also clearly appears in the article "Cuisine chypriote et cuisine grecque" (Cypriot cuisine, Greek cuisine) in which Yannis E. Ioannou reflects on the growing presence in Cyprus of Greek restaurants. More than a mere curiosity or a service for tourists, this implantation seems to underline the unsatisfied dream of union of with Greece.

9 "Jeûner pour une offrande corporelle dans le Deungsinbul (Mi-bouddha, mi-homme) de Kim Dong-Ri” (Fasting for a bodiliy offering in the Deungsinbul (half-Buddha, half-man by Kim Dong-Ri) by Min Sook Wang-Le focuses on the representation of the selfimmolation and offering of the body in the short story "Half-Buddha, Half-man" (1961)written by Kim Dong-Ri (1913-1995). The search for Buddhism and food abstinence are at the core of a reflexion starting with autobiographic elements and reaching the final scene of the offering of his human body to Buddha, as an ascetic symbolic of self-renunciation.

10 Jean-Pierre GIRAUD in "Dieux et défunts au Japon : La grande bouffe" (gods and the deceased in Japan: La grande bouffe" dares to draw a parallel with the eponymous film of Marco Ferreri to illustrate the lavish offerings to the gods and the dead in Japan in both Shintoist as Buddhist practices. Rice, salt and sake are laid on ritual trays, offerings often accompanied by tangerines or rice-cakes. The focus here is the origin of such practices that are to be found in the funeral rites of older Japan as well as in the founding myths such as they appear in the eighth-century Kojiki 古事記 (or Records of Ancient Matters).

\section{The Body, Diet, Risk and Health}

11 As food scandals and the consequences of pesticides on the environment become more and more common, what, textual, relations do we find between body, food and health? Even if "Organic" food is much publicised today, we may question the array of practices that this planetary notion implies. In particular, we note the development of information relating to risks (television programmes, publications, blogs). Facing the world-wide circulation of food, its mass importation, its increasingly distant and complex origins, there arise desires and discourses on the local and the authentic that are the particularities of local culture. Diets travel too, that of from the South-West Franc to Okinawa's . Slow food, street food, fast-food and Mac'baguettes, local/global/ glocal, quantity/quality all imply a particular relationship to globalization and the desire for "real" taste.

Discourses encourage, dissuade/forbid the eating of such and such a food. Medicines and media play an important part with injunction varying from one culture to another, or from one period to another in the same country. Eating, meeting, self-respect, losing weight, gaining weight, obesity/anorexia, desire for life or death: images of the self and diets, moderation and excess rule our physical and psychological life. The refusal to eat can also be considered a form of resistance, whilst loss of appetite often is the sign of a depression. It is also the case with consumption of alcohol.

13 "Se nourrir des souffles et des saveurs: la diététique de la médecine chinoise" (Breathing and eating: Alimentology in Chinese medicine) by Eric Marié, 


\section{(1)} of ancient China, via the contemporary banquets, all cultures associate feasting with pleasure and partying. To each, of course, their own idea of luxury. Wine, sake, beer, ouzo have long been celebrated in texts. In their aesthetic quest, cook associate the quality of presentation with gastronomic finesse, whereas the picnic represents pleasure in simplicity. From the bitter to the crisp, the writings on food have played on the language of flavours and consistencies; the memory too can be associated with these lessons in hedonism, while the ritual of meal and sharing food is one of the key phases of seduction. European advertisements are a perfect example of the associations between culinary indulgence, sexuality and eroticism. What about other cultures? Children's literature often grants a large part to the oral desires, the longed-for food appearing side by side with the fear of being eaten. If the origin of the names for foods testify to long-standing global flow of flavours, one must question present-day homogenisation of eating.

In "Gastronomie et manièrisme: l'art de manger en France à partir du XVIII siècle" (Gastronomy and mannerism: The art of eating in France from the eighteenth-century onwards), Lawrence Gasquet discusses about the beginnings of French intellectual and aesthetic interest concerning the judgement of taste and the legitimacy of food as an artistic material. The article particularly explores the works of Antonin Carême (1783-1833), an creator-chef of architectural pastries who resolutely turned modern cooking into gastronomic refinement gastronomy and transformed the turned aliment into trope. 
Geneviève Lheureux in "Banquets et anti-banquets dans l'oeuvre shakespearienne" (banquets and anti-banquets in the works of Shakespeare) offers a re-reading of Shakespeare's main texts through the elements connected to food and meals and compares them to various alimentological texts of the Elizabethan period. This analysis makes possible a panorama of alimentary practices in the seventeenth century, especially those of festive meals, more numerous on stage than everyday meals and reveals how the natural act of eating becomes an anti-natural act of transgression .

In "Cet abject objet du désir : nourriture en anamorphose dans The Hours de Michael Cunningham et l'adaptation filmique de Stephen Daldry" (This abject object of desire: Food and anamorphosis in The Hours of Michael Cunningham and it cinematographic adaptation by Stephen Daldry), Catherine Delesalle compares the novel The Hours (1998) by Michael Cunningham and its film adaptation (2002) by Stephen Daldry so as to decipher the part played by food on the same crucial day lived differently lived by three women. Symbolic of their way of being (ill at ease) in the world, of their affective relationships and of their relation to creation, food takes differing functions that balance between the drive to live and the drive to die.

22 Paloma Otaola in "Cuisine et Bonheur : la philosophie de Ferrian Adrià" (Cuisine and happiness: The philosophy of Ferrian Adrià) relates the approach of this chef who is so emblematic of contemporary Spanish cuisine. Various elements explaining the worldwide success of this great chef are examined: his biography, the mediatisation, the revolutionary aspect of his approach to cooking by deconstructing, the Spherification technique, the principle of balancing aliments, the recourse to other artistic forms, the happiness born of the magic of constant novelty, but also the care taken by the chef in transmitting his recipes in a clear language.

In "Woman \& Home : la "ménagère", le publicitaire et l'agro-alimentaire" (Woman \& Home: The "housewife", the advertiser and the food processing industry) Muriel CasselPicot analyses advertisements appearing in Woman and Home over the space of a year, to reveal what we can learn about British society. Globally the discourse to be found in these texts does not show much originality, the advertisement mainly showing manufactured products that make one's mouth water, depict the alimentary activity appear as individual and individualistic one that allows one to compete rather than share, and represents an extremely traditional partition of masculine and feminine roles and presents the larger social group that is the nation via an exoticisation of the Other. However, in the face of such stereotypes, culinary design appears as a space of inventiveness.

24 Maria Merino in "L'alimentation et le sourire : la communication corporative chez Danone" (Feeding the smile: Danone's corporate communication) examines the "Danone feeds your smile" advertising campaign launched by Danone in 2013 during Spain's economic. Pointing out the recent changes in the communication strategy of this important firm, the author relates its history and notes that the health factor was in the past a leading argument whereas now a what is favoured is a global image reconciling the qualities of the product and the firm, with Danone opting for emotion, the smile, proximity and confidence in the future.

Traduit du français par Paul SOLLY et Gregory LEE 


\section{AUTHOR}

\section{CLAIRE DODANE}

Claire DODANE, professeure de langue et littérature japonaises à l'Université Jean Moulin Lyon 3, membre de l'Institut d'Etudes Transtextuelles et Transculturelles (IETT, EA 4186) dont elle a été la directrice (2010-2015) est spécialiste des femmes écrivains du Japon moderne. Elle a, entre autres, publié l'étude Yosano Akiko, poète de la passion et figure de proue du féminisme japonais (POF, 2000), la traduction de nouvelles de la romancière Higuchi Ichiyô (1872-1896) (La Treizième nuit, Les Belles Lettres, 2008) et Cheveux emmêlés (Les Belles Lettres, 2010), traduction intégrale du premier recueil de tanka de Yosano Akiko (1878-1942).En 